\title{
Adhesion Molecules in Human Trophoblast - A Review. II. Extravillous Trophoblast
}

DOI:

10.1016/j.placenta.2008.12.003

\section{Document Version}

Accepted author manuscript

Link to publication record in Manchester Research Explorer

\section{Citation for published version (APA):}

Harris, L. K., Jones, C. J. P., \& Aplin, J. D. (2009). Adhesion Molecules in Human Trophoblast - A Review. II. Extravillous Trophoblast. Placenta, 30(4), 299-304. https://doi.org/10.1016/j.placenta.2008.12.003

\section{Published in:}

Placenta

\section{Citing this paper}

Please note that where the full-text provided on Manchester Research Explorer is the Author Accepted Manuscript or Proof version this may differ from the final Published version. If citing, it is advised that you check and use the publisher's definitive version.

\section{General rights}

Copyright and moral rights for the publications made accessible in the Research Explorer are retained by the authors and/or other copyright owners and it is a condition of accessing publications that users recognise and abide by the legal requirements associated with these rights.

\section{Takedown policy}

If you believe that this document breaches copyright please refer to the University of Manchester's Takedown Procedures [http://man.ac.uk/04Y6Bo] or contact uml.scholarlycommunications@manchester.ac.uk providing relevant details, so we can investigate your claim.

\section{OPEN ACCESS}




\title{
Adhesion molecules in human trophoblast - A review II Extravillous trophoblast
}

\author{
LK Harris*, CJP Jones and JD Aplin
}

Maternal and Fetal Health Research Group, University of Manchester, St Mary's Hospital, Manchester M13 OJH, UK

Running title: Adhesion molecules in extravillous trophoblast

10

* Corresponding author

15 Email address: john.aplin@manchester.ac.uk 


\section{Introduction}

Migratory trophoblast undergoes a radical alteration in its repertoire of adhesion molecules as it escapes from the villous placenta and colonises maternal decidua (Figure 1a), spiral

20 arteries and myometrium. Following the discovery that the expression of adhesion molecules by extravillous trophoblast (EVT) is dysregulated in pathological pregnancy, interest in this area of research has intensified. Nonetheless, data from functional studies are scarce, reflecting the limitations of current in vitro culture models. In the following review we summarise current knowledge of adhesion systems in extravillous trophoblast.

25 Further information on the cell biology of placental development and trophoblast invasion can be found elsewhere $[1,2]$.

\section{Integrins}

A plethora of studies carried out over the past twenty years has documented the expression

30 of integrin subunits in villous and extravillous trophoblast, and described the integrin switch that characterizes acquisition of an invasive phenotype, as trophoblasts differentiate, detach and invade the decidua (Figure 1a). Cells in the columns upregulate the fibronectin receptor integrin $\alpha 5 \beta 1$ [3-11], the fibronectin, VCAM-1 and EMILIN-1 receptor $\alpha 4 \beta 1$ [12], $\alpha \mathrm{V} \beta 3$ [12], which binds fibronectin and other RGD-containing ligands in extracellular matrix (ECM), the

35 laminin/collagen receptor $\alpha 1 \beta 1$ and the laminin receptor $\alpha 6 \beta 1$. They exhibit a reciprocal loss of expression of the laminin receptor $\alpha 6 \beta 4[4,6,13-16]$.

Functional studies examining the role of integrins in mediating invasion of primary cytotrophoblasts (CTB) through a basement membrane-like matrix (Matrigel) and interstitial collagen have demonstrated the importance of $\alpha \vee \beta 3$ and $\alpha 1 \beta 1$ in promoting migration and of $\alpha 5 \beta 1$ in anchorage $[5,6,8,12]$. Function-blocking antibodies raised against $\beta 1$ disturb anchorage and reduce column outgrowth when applied to villous explants, and shift the balance of interactions away from cell-matrix and towards cell-cell adhesion [8]. Antibodies against laminin, collagen IV or integrin $\alpha 1$ inhibit invasion in vitro, implicating a role for the 
$\alpha 1 \beta 1$ - laminin or $\alpha 1 \beta 1$-collagen IV interactions. Conditions of reduced trophoblast invasion

45 have also been observed when $\alpha 1 \beta 1$ expression is either maintained (but combined with an altered protease profile, as in vitro after TNF $\alpha$ treatment [13]) or reduced (as in vitro under hypoxia [14]).

Initially, within and nearby the cell columns, CTB interacts with a type of provisional

50 ECM known as matrix-type fibrinoid (Figure 2a, b) that contains fibronectin [17], the ligand for integrin a5 $\beta 1$, and vitronectin, which ligates av $\beta 3$, as well as the basement membrane ligands laminin and collagen IV which bind a1ß1. Fibrinoid accumulates between the cells and at the periphery of columns and probably anchors the columns to the maternal surface [18]. Decidual ECM is also enriched in laminins, collagen IV $[19,20]$ and fibronectin [19,

55 21]. Interaction of CTB with the stromal and vascular wall fibrillar component EMILIN-1 occurs by binding to integrin $\alpha 4 \beta 1$, leading to haptotactic migration and upregulation of matrix metalloproteinase (MMP) activity [22].

The effect of hypoxia on integrin expression in EVT has received attention as a potential mediator of altered depth of trophoblast invasion in preeclampsia (see below). EVT

60 outgrowths from first trimester placental explants cultured on ECM substrates at 2\%, 3\%, $8 \%$ or $20 \%$ oxygen $[8,23,24]$ express integrin a $5 \beta 1$, indicating that an EVT differentiation programme is initiated as cells contact the ECM. In some studies, integrin a1 upregulation has been reported not to occur at $2 \%$ oxygen, correlating with a lower migratory activity in Matrigel $[14,25]$. It has been suggested that this effect on integrin $a 1$ is controlled by HIF $1 \alpha$

65 [24]. These data suggest that hypoxia permits initiation, but not completion of the normal integrin switching program.

Decreased integrin a1 expression and reduced invasion is also noted when vascular endothelial growth factor (VEGF), signaling through VEGF receptor-1 (VEGF-R1) or VEGFR-3, is inhibited in primary first trimester CTB by a VEGFR-Fc fusion protein [26]. As VEGFR-1 and R-3 are highly expressed in the distal cell column and in interstitial EVT during the first 
and second trimesters, with R-3 expression also prominent in endovascular trophoblast [26], it is conceivable that trophoblast-derived VEGF may promote invasion in an autocrine manner by enhancing $\alpha 1$-mediated migration.

Insulin-like growth factors stimulate trophoblast migration [27], and the insulin-like

75 growth factor binding protein-1 (IGFBP-1), a secretory product of decidual cells, may independently modulate trophoblast invasion in the placental bed. IGFBP-1 contains an RGD sequence motif that binds $\alpha 5 \beta 1$ and disrupts trophoblast binding to fibronectin, resulting in enhanced migration in vitro [15]. CD9, a tetraspanin glycoprotein whose expression in the placenta is associated with $\alpha 3$ and $\alpha 5$ integrins, may also mediate trophoblast adhesion

80 [28]. CD9 is absent from villous CTB, but is upregulated in cell columns and is highly expressed by EVT.

The presence of fibronectin molecules bearing a unique glycopeptide domain (termed oncofetal fibronectin or onfFN) within the type III connecting segment, has been noted within the placental bed. Immunohistochemical analysis has revealed the presence of onfFN

85 in the extracellular matrix that connects extravillous anchoring trophoblasts and trophoblast cell columns to the uterine wall [21], and cell culture studies have confirmed that EVT produce and secrete onfFN in vitro [8, 21, 29]. However, not all cells in EVT subpopulations produce onfFN to the same extent. A subset of invasive EVT expressing $\alpha 6$ integrin and HLA-G produce high levels of gelatinases but secrete little onfFN, whereas EVT cells that 90 express $\alpha 5$ integrin secrete low levels of gelatinases, produce large amounts of onfFN and show reduced invasion [30]. This suggests that alterations in invasive phenotype that lead to enhanced onfFN production may result in autocrine regulation of trophoblast adhesion. Transforming growth factor- $\beta 1$ (TGF- $\beta 1$ ) has been shown to stimulate onfFN production by trophoblast [29], suggesting that local gradients of exogenous cytokines within the placental

95 bed could modulate trophoblast adhesion in defined locations. Further discussion can be found in a recent review [31]. 
$\operatorname{av} \beta 3 / \beta 5$ and $\beta 1$ integrins mediate adhesion of human CTB to endothelial cells in vitro, suggesting that they may facilitate endovascular trophoblast adhesion and migration within uterine arteries [32]. CTB expressing $\alpha 4$ integrin bind the vascular cell adhesion 100 molecule VCAM-1, indicating that $\alpha 4 \beta 1$ may mediate CTB-endothelium or CTB-CTB interactions during endovascular invasion [12]. Macaque CTB similarly express av $\beta 3$ and $\beta 1$ integrins, and upregulate $\beta 1$ in response to shear stress or co-culture with uterine microvascular endothelial cells $[16,33,34]$. Migration of macaque CTB toward vitronectin, and adhesion of CTB to myometrial endothelial cells in co-culture is mediated by integrin $105 \operatorname{av} \beta 3 / \beta 5$.

The serious pregnancy complication of pre-eclampsia is characterised by shallow interstitial EVT invasion, reduced endovascular invasion and an absence of remodelling in myometrial artery segments. Decreased invasion has been attributed to the failure of differentiating CTB to adopt an invasive phenotype: trophoblasts emigrating from cell

110 columns show persistence of integrin $\alpha 6 \beta 4$ expression and fail to upregulate $\alpha v \beta 3$ and $\alpha 1 \beta 1$ $[7,35,36]$. These findings suggest that pre-eclampsia is associated with failure or delay of a CTB differentiation programme, with retention of cell adhesion molecules that under normal conditions are only expressed by villous progenitor cells and CTB in the proximal region of the cell column. However, another study has reported that expression of $\beta 1$ 115 integrins in trophoblast is similar in healthy women and women with pre-eclampsia or preterm labour [37]. Some heterogeneity in the expression of different integrin $\alpha$ subunits was noted, with variation being observed in each study group. Simultaneous expression of $\alpha 1$, $\alpha 3, \alpha 5$ and $\alpha 6$ integrins may be important for migration of EVT[38]. Atypical integrin expression has also been described in ectopic pregnancy: EVT have been reported to display 120 prominent expression of $\alpha 6$ and $\beta 4$ subunits, despite exhibiting invasive behaviour [38]. 


\section{Immunoglobulin family cell adhesion molecules (CAMs)}

125 Neural cell adhesion molecule (NCAM; CD56) is a cell surface glycoprotein that mediates homophilic binding. Human endovascular trophoblasts express a unique polysialylated form of NCAM which may moderate the strength of trophoblast interactions [39]. NCAM expression has been observed in trophoblast plugs within the spiral arteries but is absent from villous CTB, syncytiotrophoblast (STB) and cell columns. A similar

130 distribution of NCAM has been noted in the macaque: endovascular and perivascular trophoblast stain for NCAM, but intramural trophoblast exhibit little immunoreactivity [40]. These findings suggest that NCAM is necessary for endovascular invasion, aiding binding of trophoblast to the arterial endothelium or to vascular extracellular matrix components.

Platelet-endothelial cell adhesion molecule-1 (PECAM-1; CD31)[41] is an

135 immunoglobulin superfamily member that acts as both a heterophilic and homophilic adhesion molecule and may mediate the attachment of trophoblast to the vascular endothelium. Its proposed ligands include integrin $\alpha \vee \beta 3[41]$. Like NCAM, PECAM-1 expression has been described in human perivascular and endovascular trophoblasts [12, 42, 43], but also in interstitial EVT and in CTB of the distal column [36]. However, these

140 findings have been disputed by other groups, who observed PECAM-1 expression exclusively in spiral artery endothelium throughout gestation and not in villous or extravillous trophoblast $[44,45]$. It has been reported that PECAM-1 upregulation by endovascular trophoblast fails in pre-eclampsia [12], although other studies have shown no difference in its expression between normotensive and pre-eclamptic pregnancies [44, 45]. Interestingly,

145 PECAM-1 is expressed by endovascular trophoblasts in healthy rats as well as in a rat model of pre-eclampsia [46], and PECAM-1 expression is upregulated at points of contact between CTB and endothelial cells in vitro [42, 43]. PECAM-1 is also expressed in endovascular trophoblasts and vascular endothelial cells of the macaque, although expression is often reduced in EVT distal to the arterial lumen. The spiral artery endothelium is observed to 150 retain PECAM-1 reactivity even after vessel remodelling [47]. Since PECAM-1 plays a role in 
transendothelial migration of leukocytes [41], it is possible that it may function in trophoblast invasion, as cells cross either from the vessel lumen to the wall, or in the reverse direction.

Melanoma cell adhesion molecule (Mel-CAM; MUC18; CD164) is an adhesion molecule 155 that mediates heterophilic binding to an unidentified ligand and has been shown to be important in tumor progression. Mel-CAM is expressed by the majority of EVT, is present on endothelial and myometrial cells but is absent from villous CTB and STB [48, 49]. It is present on invasive trophoblast in the mouse, where antibody-mediated blockade leads to pregnancy failure [50]. Cell culture studies have demonstrated the presence of a putative 160 Mel-CAM ligand on uterine smooth muscle cells and have shown that disruption of Mel-CAM binding promotes migration of an EVT cell line [51].

Intercellular adhesion molecule-1 (ICAM-1) and vascular cell adhesion molecule-1 (VCAM-1) are other members of the immunoglobulin superfamily that mediate adhesion of leukocytes to the vascular endothelium. ICAM-1 is expressed by vascular endothelial cells

165 throughout the decidua; however, expression of VCAM-1 is variable at the implantation site and it is only seen in vascular endothelial cells in the decidua basalis [39]. VCAM-1 is expressed by CTB in the distal portion of the cell column, and by both interstitial and endovascular EVT [36]. In common with the failure to alter their integrin repertoire, invasive CTB from pregnancies complicated with pre-eclampsia do not upregulate VCAM-1 170 expression.

There has been some speculation that ICAM-1, VCAM-1 and PECAM-1 may mediate adhesion of endovascular trophoblasts to the walls of spiral arteries. Studies of early gestation macaque trophoblast have shown that ICAM-1-blocking antibodies reduce transendothelial migration in vitro [52]. The same study demonstrated that antibodies 175 against the mucin MUC-1, which is expressed by macaque endovascular EVT, reduced adhesion of isolated trophoblast to uterine endothelial cells and inhibited trophoblast transendothelial migration. These data predict that both ICAM-1 and MUC-1 may be 
mediators of mural invasion in human pregnancy. It should be noted that MUC-1 antibodies mark a subset of human interstitial EVTs, suggesting that the EVT population contains cells 180 that vary in their potential to colonise vessels [53].

\section{Selectins}

Selectins are a family of single-chain transmembrane glycoproteins that bind oligosaccharides and permit transient tethering and shear stress-dependent rolling. Both E-

185 and P-selectin are expressed by human vascular endothelial cells in the decidua basalis, but are absent from the vessels of the decidua parietalis [39]. Thus they may be candidates for mediating endovascular trophoblast invasion/migration. Indeed, adhesion of isolated CTB to endothelial cells in vitro is partially blocked by antibodies to P-selectin [32]. In contrast, Lselectin is expressed by CTB in columns, with high expression noted at the distal ends [54-

190 56]. L-selectin is also strongly expressed by EVT and may be important for establishing and maintaining column architecture, based on the observation that function-perturbing antibodies inhibit column formation in vitro [55].

\section{Cadherins}

195 VE-cadherin (VE-cad), a marker of the endothelial cell lineage, is absent from villous CTB but is expressed by trophoblast cell columns, interstitial EVT and spiral artery endothelial cells $[12,36,38]$. Following loss of the vascular endothelium during arterial remodelling, VE-cad expression is further upregulated in endovascular and mural CTB, reflecting their acquisition of certain features of the endothelial phenotype [12, 42]. Antibodies to VE-cad

200 reduce CTB adhesion, migration and invasion across Matrigel barriers in vitro, suggesting a role in interaction with extracellular matrix $[12,42]$. VE-cad expression is also required for first trimester trophoblast cells to bind to decidual endothelial cells in vitro [36], and failure of invasive CTB to upregulate VE-cad expression is noted in pre-eclampsia $[12,36,57]$. 
In contrast to VE-cad, E-cadherin (E-cad) expression is observed throughout

205 anchoring villi, with cells detaching from the distal ends of columns and individual interstitial EVT exhibiting reduced, discontinuous expression [57]. When present in aggregates, interstitial, intraluminal, perivascular and endovascular EVT express E-cad, although discontinuous membrane expression is observed in lone cells [58]. Isolated CTB cultured on basement membrane-like ECM express E-cad, and anti-E-cad antibodies enhance CTB

210 invasion [12], suggesting a role in CTB-CTB attachment. Invasive CTB in pre-eclamptic placentas have been shown to retain expression of E-cad [35].

Cadherin-11 (Cad-11) expression has been documented in EVT where it is located at the tips of cell columns [59]. Although little work has been done to elucidate its role, Cad11 may be important in promoting adhesion of trophoblast to maternal stromal cells, where

215 it is upregulated during decidualization [60]. Similarly, expression of dysadherin, a cell surface glycoprotein thought to reduce cell-cell adhesion and increase motility, is increased in CTB developing into columns $[61,62]$. Dysadherin is believed to promote cell migration via effects on the actin cytoskeleton and downregulation of E-cadherin expression [57, 58].

\section{6. Kisspeptins}

Kisspeptin, the 145 residue polypeptide product of the KiSS-1 gene, is proteolytically processed to generate smaller peptides containing 54 (Kp-54; metastin), 14 (Kp-14), 13 $(\mathrm{Kp}-13)$ or $10(\mathrm{Kp}-10)$ amino acids. Kisspeptins are endogenous ligands for the G proteincoupled KiSS-1 receptor (KiSS-1R) and both kisspeptin and KiSS-1R are highly expressed

225 during the first trimester of pregnancy. KiSS $-1 / \mathrm{Kp}-54$ protein expression is restricted to the STB, whereas KiSS-1R is expressed by the STB and by villous and extravillous CTB [63-66]. In addition, $\mathrm{Kp}-54, \mathrm{Kp}-14, \mathrm{Kp}-13$ and $\mathrm{Kp}-10$ are produced by first trimester trophoblast in vitro, although only $\mathrm{Kp}-10$ has been shown to mediate significant physiological effects. $\mathrm{Kp}$ 10 reduced CTB outgrowth from villous explant culture and inhibited migration and MMP-2 230 expression in isolated human first trimester trophoblasts. As KiSS-1R is expressed on both 
villous and extravillous CTB, secretion of kisspeptins by the syncytium may allow paracrine regulation of invasion and column formation.

\section{Ephrins}

235 The receptor tyrosine kinase EPHB4 and its ligands ephrin-B1 and ephrin-B2 may play a role in trophoblast adhesion. In early gestation, ephrin-B1 is expressed by interstitial and endovascular EVT, and ephrin-B2 expression is observed in both villous CTB and EVT [61, 62]. Studies of EVT differentiation have revealed that acquisition of an invasive phenotype is associated with a rapid decrease in EPHB4 expression and enhanced expression of ephrin-

240 B1 and -B2. Indeed, during differentiation of villous CTB at the proximal region of the cell column, EPHB4 expression is downregulated in favour of enhanced expression of ephrin B1. As substrates containing an EPHB4-Fc fusion protein decrease adhesion and reduce migration of CTB in vitro, and EPHB4 is expressed by the uterine venous endothelium, this may explain why EVT do not colonize the uterine veins. Conversely, ephrin B2-Fc fusion

245 proteins support CTB migration in vitro, thus expression of ephrin-B2 by the spiral artery endothelium may promote preferential arterial remodelling.

\section{Junctional proteins}

Within the anchoring column, CTB are linked by desmosomes which are associated with

250 extensive arrays of cytoplasmic intermediate filaments (Figure 1b) [67, 68]. The tight junctional proteins occludin and zona occludens-1 (ZO-1) are also present, but it is not yet clear what functional contribution they may make [69]. Sometimes arrays of fine submembranous filaments are visible at cell interfaces (Figure 1c). Emigration of CTB from the column (Figure 1a) is concomitant with fracture and loss of desmosomes (Figure 2a) and

255 loss of ZO-1 and occludin [69, 70]. Similarly, connexin 40-containing gap junctions (Figure 2b) are decreased during differentiation of CTB into a more invasive phenotype [66]. Downregulation of connexin 40 , or experimental inhibition of gap junction function, are both 
associated with differentiation and an increase in expression of $\alpha 1$ integrin [70, 71]. Furthermore, factors secreted by decidua decrease connexin 40 in placental explants and trophoblast cell lines, resulting in enhanced migration and invasion [71].

\section{Conclusion}

Key transition points in trophoblast differentiation and invasion depend very obviously on alterations in intercellular adhesion: detachment of precursor EVT from the basement

265 membrane, detachment of migratory EVT from distal cell columns, de novo adhesion to the uterine extracellular matrix, and migration into maternal vascular and interstitial tissue compartments require acquisition of motility and significant alterations in the adhesion molecule repertoire. Adhesion molecules upregulated during differentiation of CTB in the cell column include VCAM-1, PECAM-1, L-selectin, VE-cad, CAD-11, CD9, ephrin-B1 and -B2, and 270 the integrins $\alpha 5 \beta 1, \alpha 4 \beta 1, \alpha 1 \beta 1$ and $\alpha 6 \beta 1$. A reciprocal decrease in the expression of Ecad, EphB4, desmosomes, Cx40 gap junctions and integrin $\alpha 6 \beta 4$ is also observed. Endovascular and interstitial trophoblast maintain expression of VE-cad, PECAM-1, ephrin-B1 and -B2, and upregulate Mel-CAM; endovascular EVT also express NCAM.

Cell contact, and the signalling events that follow downstream, play a profound role 275 in the control of proliferation, death, migration and invasion in the uterine environment. A better understanding of trophoblast migration and the regulation of the molecular switches that make it possible will be critical in addressing pathologies of pregnancy including preeclampsia [72-74], preterm labour [75], late miscarriage [76], hypertension, [77] and IUGR [74, 78], in which trophoblast migration and maternal vascular remodelling are impaired. 


\section{References}

[1] Pijnenborg R, Vercruysse L, Hanssens $M$. The uterine spiral arteries in human pregnancy: facts and controversies. Placenta 2006;27:939-58.

285 [2] Aplin J, Jones C. Human placental development. In: Aplin J, Fazleabas A, Glasser S, Giudice L (eds.), The Endometrium. London: Informa; 2008: 422-31.

[3] Vicovac L, Aplin JD. Epithelial-mesenchymal transition during trophoblast differentiation. Acta Anat (Basel) 1996;156:202-16.

[4] Aplin JD. Expression of integrin alpha 6 beta 4 in human trophoblast and its loss from extravillous cells. Placenta 1993;14:203-15.

[5] Damsky CH, Librach C, Lim KH, Fitzgerald ML, McMaster MT, Janatpour M, Zhou Y, Logan SK, Fisher SJ. Integrin switching regulates normal trophoblast invasion. Development 1994;120:3657-66.

[6] Vicovac L, Jones CJ, Aplin JD. Trophoblast differentiation during formation of anchoring villi in a model of the early human placenta in vitro. Placenta $1995 ; 16: 41$ 56.

[7] Zhou Y, Damsky CH, Chiu K, Roberts JM, Fisher SJ. Preeclampsia is associated with abnormal expression of adhesion molecules by invasive cytotrophoblasts. J Clin Invest $1993 ; 91: 950-60$.

300 [8] Aplin JD, Haigh T, Jones CJ, Church HJ, Vicovac L. Development of cytotrophoblast columns from explanted first-trimester human placental villi: role of fibronectin and integrin alpha5beta1. Biol Reprod 1999;60:828-38.

[9] Damsky $\mathrm{CH}$, Fitzgerald $\mathrm{ML}$, Fisher S]. Distribution patterns of extracellular matrix components and adhesion receptors are intricately modulated during first trimester cytotrophoblast differentiation along the invasive pathway, in vivo. J Clin Invest $1992 ; 89: 210-22$. 
[10] Korhonen M, Ylanne J, Laitinen L, Cooper HM, Quaranta V, Virtanen I. Distribution of the alpha 1-alpha 6 integrin subunits in human developing and term placenta. Lab Invest $1991 ; 65: 347-56$.

310 [11] Aplin JD. Adhesion molecules in implantation. Rev Reprod 1997;2:84-93.

[12] Zhou Y, Fisher SJ, Janatpour M, Genbacev O, Dejana E, Wheelock M, Damsky CH. Human cytotrophoblasts adopt a vascular phenotype as they differentiate. A strategy for successful endovascular invasion? J Clin Invest 1997;99:2139-51.

[13] Bauer S, Pollheimer J, Hartmann J, Husslein P, Aplin JD, Knofler M. Tumor necrosis factor-alpha inhibits trophoblast migration through elevation of plasminogen activator inhibitor-1 in first-trimester villous explant cultures. J Clin Endocrinol Metab $2004 ; 89: 812-22$.

[14] Genbacev O, Joslin R, Damsky $\mathrm{CH}$, Polliotti BM, Fisher SJ. Hypoxia alters early gestation human cytotrophoblast differentiation/invasion in vitro and models the placental defects that occur in preeclampsia. J Clin Invest 1996;97:540-50.

[15] Irving JA, Lala PK. Functional role of cell surface integrins on human trophoblast cell migration: regulation by TGF-beta, IGF-II, and IGFBP-1. Exp Cell Res 1995;217:41927.

[16] Thirkill TL, Hendren SR, Soghomonians A, Mariano NF, Barakat AI, Douglas GC. Regulation of trophoblast beta1-integrin expression by contact with endothelial cells. Cell Commun Signal 2004;2:4.

[17] Huppertz B, Kertschanska S, Frank HG, Gaus G, Funayama H, Kaufmann P. Extracellular matrix components of the placental extravillous trophoblast: immunocytochemistry and ultrastructural distribution. Histochem Cell Biol $1996 ; 106: 291-301$.

[18] Kaufmann P, Huppertz B, Frank HG. The fibrinoids of the human placenta: origin, composition and functional relevance. Ann Anat 1996;178:485-501. 
[19] Aplin JD, Charlton AK, Ayad S. An immunohistochemical study of human endometrial extracellular matrix during the menstrual cycle and first trimester of pregnancy. Cell Tissue Res 1988;253:231-40.

[20] Church H, Richards A, Aplin J. Laminins in decidua, placenta and choriocarcinoma cells. Trophoblast Research 1996;10:143-62.

[21] Feinberg RF, Kliman $\mathrm{HJ}$, Lockwood CJ. Is oncofetal fibronectin a trophoblast glue for human implantation? Am J Pathol 1991;138:537-43.

340 [22] Spessotto P, Bulla R, Danussi C, Radillo O, Cervi M, Monami G, Bossi F, Tedesco F, Doliana R, Colombatti A. EMILIN1 represents a major stromal element determining human trophoblast invasion of the uterine wall. J Cell Sci 2006;119:4574-84.

[23] Araki-Taguchi M, Nomura S, Ino K, Sumigama S, Yamamoto E, Kotani-Ito T, Hayakawa H, Kajiyama H, Shibata K, Itakura A, Kikkawa F. Angiotensin II mimics the hypoxic effect on regulating trophoblast proliferation and differentiation in human placental explant cultures. Life Sci 2008;82:59-67.

[24] Caniggia I, Mostachfi H, Winter J, Gassmann M, Lye SJ, Kuliszewski M, Post M. Hypoxia-inducible factor-1 mediates the biological effects of oxygen on human trophoblast differentiation through TGFbeta(3). J Clin Invest 2000;105:577-87.

350 [25] Genbacev O, Zhou Y, Ludlow JW, Fisher SJ. Regulation of human placental development by oxygen tension. Science 1997;277:1669-72.

[26] Zhou Y, McMaster M, Woo K, Janatpour M, Perry J, Karpanen T, Alitalo K, Damsky C, Fisher SJ. Vascular endothelial growth factor ligands and receptors that regulate human cytotrophoblast survival are dysregulated in severe preeclampsia and hemolysis, elevated liver enzymes, and low platelets syndrome. Am J Pathol $2002 ; 160: 1405-23$.

[27] Lacey H, Haigh T, Westwood M, Aplin JD. Mesenchymally-derived insulin-like growth factor 1 provides a paracrine stimulus for trophoblast migration. BMC Dev Biol $2002 ; 2: 5$ 
360 [28] Hirano T, Higuchi T, Ueda M, Inoue T, Kataoka N, Maeda M, Fujiwara H, Fujii S. CD9 is expressed in extravillous trophoblasts in association with integrin alpha3 and integrin alpha5. Mol Hum Reprod 1999;5:162-7.

[29] Feinberg RF, Kliman HJ, Wang CL. Transforming growth factor-beta stimulates trophoblast oncofetal fibronectin synthesis in vitro: implications for trophoblast implantation in vivo. J Clin Endocrinol Metab 1994;78:1241-8.

[30] Bischof $P$, Haenggeli L, Campana A. Gelatinase and oncofetal fibronectin secretion is dependent on integrin expression on human cytotrophoblasts. Hum Reprod $1995 ; 10: 734-42$.

[31] Salamonsen LA, Hannan NJ, Dimitriadis E. Cytokines and chemokines during human 370 embryo implantation: roles in implantation and early placentation. Semin Reprod Med $2007 ; 25: 437-44$.

[32] Thirkill TL, Douglas GC. The vitronectin receptor plays a role in the adhesion of human cytotrophoblast cells to endothelial cells. Endothelium 1999;6:277-90.

[33] Soghomonians A, Barakat AI, Thirkill TL, Blankenship TN, Douglas GC. Effect of shear stress on migration and integrin expression in macaque trophoblast cells. Biochim Biophys Acta 2002;1589:233-46.

[34] Douglas GC, Thirkill TL, Blankenship TN. Vitronectin receptors are expressed by macaque trophoblast cells and play a role in migration and adhesion to endothelium. Biochim Biophys Acta 1999;1452:36-45.

380 [35] Zhou Y, Damsky CH, Fisher SJ. Preeclampsia is associated with failure of human cytotrophoblasts to mimic a vascular adhesion phenotype. One cause of defective endovascular invasion in this syndrome? J Clin Invest 1997;99:2152-64.

[36] Damsky $\mathrm{CH}$, Fisher SJ. Trophoblast pseudo-vasculogenesis: faking it with endothelial adhesion receptors. Curr Opin Cell Biol 1998;10:660-6. 
385 [37] Divers MJ, Bulmer JN, Miller D, Lilford RJ. Beta 1 integrins in third trimester human placentae: no differential expression in pathological pregnancy. Placenta $1995 ; 16: 245-60$.

[38] Dubernard G, Galtier-Fougairolles M, Cortez A, Uzan S, Challier JC. Immunohistochemistry of adhesion molecules, metalloproteinases and NO-synthases in extravillous trophoblast of tubal pregnancy. Cell Mol Biol (Noisy-le-grand) 2005;51 Suppl:OL829-37.

[39] Burrows TD, King A, Loke YW. Expression of adhesion molecules by endovascular trophoblast and decidual endothelial cells: implications for vascular invasion during implantation. Placenta 1994;15:21-33.

395 [40] Blankenship TN, King BF. Macaque intra-arterial trophoblast and extravillous trophoblast of the cell columns and cytotrophoblastic shell express neural cell adhesion molecule (NCAM). Anat Rec 1996;245:525-31.

[41] Woodfin A, Voisin MB, Nourshargh S. PECAM-1: a multi-functional molecule in inflammation and vascular biology. Arterioscler Thromb Vasc Biol 2007;27:2514-23.

400 [42] Bulla R, Villa A, Bossi F, Cassetti A, Radillo O, Spessotto P, De Seta F, Guaschino S, Tedesco F. VE-cadherin is a critical molecule for trophoblast-endothelial cell interaction in decidual spiral arteries. Exp Cell Res 2005;303:101-13.

[43] Coukos G, Makrigiannakis A, Amin K, Albelda SM, Coutifaris C. Platelet-endothelial cell adhesion molecule-1 is expressed by a subpopulation of human trophoblasts: a 405 possible mechanism for trophoblast-endothelial interaction during haemochorial placentation. Mol Hum Reprod 1998;4:357-67.

[44] Lyall F, Bulmer JN, Duffie E, Cousins F, Theriault A, Robson SC. Human trophoblast invasion and spiral artery transformation: the role of PECAM-1 in normal pregnancy, preeclampsia, and fetal growth restriction. Am J Pathol 2001;158:1713-21. 
410 [45] Pijnenborg R, Vercruysse L, Verbist L, Van Assche FA. Interaction of interstitial trophoblast with placental bed capillaries and venules of normotensive and preeclamptic pregnancies. Placenta 1998;19:569-75.

[46] Geusens N, Verlohren S, Luyten C, Taube M, Hering L, Vercruysse L, Hanssens M, Dudenhausen JW, Dechend R, Pijnenborg R. Endovascular Trophoblast Invasion, Spiral Artery Remodelling and Uteroplacental Haemodynamics in a Transgenic Rat Model of Pre-eclampsia. Placenta 2008;29:614-23.

[47] Blankenship TN, Enders AC. Expression of platelet-endothelial cell adhesion molecule1 (PECAM) by macaque trophoblast cells during invasion of the spiral arteries. Anat Rec 1997;247:413-9.

420 [48] Higuchi T, Fujiwara H, Egawa H, Sato Y, Yoshioka S, Tatsumi K, Itoh K, Maeda M, Fujita J, Fujii S. Cyclic AMP enhances the expression of an extravillous trophoblast marker, melanoma cell adhesion molecule, in choriocarcinoma cell JEG3 and human chorionic villous explant cultures. Mol Hum Reprod 2003;9:359-66.

[49] Shih IM, Kurman RJ. Expression of melanoma cell adhesion molecule in intermediate trophoblast. Lab Invest 1996;75:377-88.

[50] Liu Q, Zhang B, Zhao X, Zhang Y, Liu Y, Yan X. Blockade of adhesion molecule CD146 causes pregnancy failure in mice. J Cell Physiol 2008;215:621-6.

[51] Shih I, Wang T, Wu T, Kurman RJ, Gearhart JD. Expression of Mel-CAM in implantation site intermediate trophoblastic cell line, IST-1, limits its migration on uterine smooth muscle cells. J Cell Sci 1998;111 ( Pt 17):2655-64.

[52] Thirkill TL, Cao T, Stout M, Blankenship TN, Barakat A, Douglas GC. MUC1 is involved in trophoblast transendothelial migration. Biochim Biophys Acta 2007;1773:1007-14.

[53] Shyu MK, Lin MC, Liu CH, Fu YR, Shih JC, Lee CN, Chen HY, Huang J, Huang MC, Hsieh FJ. MUC1 expression is increased during human placental development and suppresses trophoblast-like cell invasion in vitro. Biol Reprod 2008;79:233-9. 
[54] Genbacev OD, Prakobphol A, Foulk RA, Krtolica AR, Ilic D, Singer MS, Yang ZQ, Kiessling LL, Rosen SD, Fisher SJ. Trophoblast L-selectin-mediated adhesion at the maternal-fetal interface. Science 2003;299:405-8.

[55] Prakobphol A, Genbacev O, Gormley M, Kapidzic M, Fisher S]. A role for the L-selectin adhesion system in mediating cytotrophoblast emigration from the placenta. Dev Biol $2006 ; 298: 107-17$.

[56] Zhou Y, Genbacev O, Fisher SJ. The human placenta remodels the uterus by using a combination of molecules that govern vasculogenesis or leukocyte extravasation. Ann N Y Acad Sci 2003;995:73-83.

445 [57] Floridon C, Nielsen O, Holund B, Sunde L, Westergaard JG, Thomsen SG, Teisner B. Localization of E-cadherin in villous, extravillous and vascular trophoblasts during intrauterine, ectopic and molar pregnancy. Mol Hum Reprod 2000;6:943-50.

[58] Fisher SJ, Cui TY, Zhang L, Hartman L, Grahl K, Zhang GY, Tarpey J, Damsky CH. Adhesive and degradative properties of human placental cytotrophoblast cells in vitro. J Cell Biol 1989;109:891-902.

[59] MacCalman CD, Getsios S, Chen GT. Type 2 cadherins in the human endometrium and placenta: their putative roles in human implantation and placentation. Am J Reprod Immunol 1998;39:96-107.

[60] Chen GT, Getsios S, MacCalman CD. Cadherin-11 is a hormonally regulated cellular 455 marker of decidualization in human endometrial stromal cells. Mol Reprod Dev $1999 ; 52: 158-65$.

[61] Ino $Y$, Gotoh M, Sakamoto M, Tsukagoshi K, Hirohashi S. Dysadherin, a cancerassociated cell membrane glycoprotein, down-regulates E-cadherin and promotes metastasis. Proc Natl Acad Sci U S A 2002;99:365-70.

460 [62] Batistatou A, Makrydimas G, Zagorianakou N, Zagorianakou P, Nakanishi Y, Agnantis NJ, Hirohashi S, Charalabopoulos K. Expression of dysadherin and E-cadherin in trophoblastic tissue in normal and abnormal pregnancies. Placenta 2007;28:590-2. 
[63] Bilban M, Ghaffari-Tabrizi N, Hintermann E, Bauer S, Molzer S, Zoratti C, Malli R, Sharabi A, Hiden U, Graier W, Knofler M, Andreae F, Wagner O, Quaranta V, Desoye 465 G. Kisspeptin-10, a KiSS-1/metastin-derived decapeptide, is a physiological invasion inhibitor of primary human trophoblasts. J Cell Sci 2004;117:1319-28.

[64] Hiden U, Bilban M, Knofler M, Desoye G. Kisspeptins and the placenta: regulation of trophoblast invasion. Rev Endocr Metab Disord 2007;8:31-9.

[65] Chennakesava CS, Di Santo S, Ziemiecki A, Schneider H, Andres AC. Differential expression of the receptor tyrosine kinase EphB4 and its ligand Ephrin-B2 during human placental development. Placenta 2006;27:959-67.

[66] Red-Horse K, Kapidzic M, Zhou Y, Feng KT, Singh H, Fisher S]. EPHB4 regulates chemokine-evoked trophoblast responses: a mechanism for incorporating the human placenta into the maternal circulation. Development 2005;132:4097-106.

475 [67] Enders AC, Blankenship TN, Fazleabas AT, Jones CJ. Structure of anchoring villi and the trophoblastic shell in the human, baboon and macaque placenta. Placenta $2001 ; 22: 284-303$.

[68] Enders AC. Fine structure of anchoring villi of the human placenta. Am J Anat $1968 ; 122: 419-51$.

480 [69] Marzioni D, Banita M, Felici A, Paradinas FJ, Newlands E, De Nictolis M, Muhlhauser J, Castellucci M. Expression of ZO-1 and occludin in normal human placenta and in hydatidiform moles. Mol Hum Reprod 2001;7:279-85.

[70] Nishimura T, Dunk C, Lu Y, Feng X, Gellhaus A, Winterhager E, Rossant J, Lye S]. Gap junctions are required for trophoblast proliferation in early human placental development. Placenta 2004;25:595-607.

[71] Wright JK, Dunk CE, Perkins JE, Winterhager E, Kingdom JC, Lye S]. EGF modulates trophoblast migration through regulation of Connexin 40. Placenta 2006;27 Suppl A:S114-21. 
[72] Meekins JW, Pijnenborg R, Hanssens M, McFadyen IR, van Asshe A. A study of 490 placental bed spiral arteries and trophoblast invasion in normal and severe preeclamptic pregnancies. Br J Obstet Gynaecol 1994;101:669-74.

[73] Aardema MW, Oosterhof H, Timmer A, van Rooy I, Aarnoudse JG. Uterine artery Doppler flow and uteroplacental vascular pathology in normal pregnancies and pregnancies complicated by pre-eclampsia and small for gestational age fetuses. $495 \quad$ Placenta $2001 ; 22: 405-11$.

[74] Gerretsen G, Huisjes HJ, Elema JD. Morphological changes of the spiral arteries in the placental bed in relation to pre-eclampsia and fetal growth retardation. $\mathrm{Br} \mathrm{J}$ Obstet Gynaecol 1981;88:876-81.

[75] Kim YM, Bujold E, Chaiworapongsa T, Gomez R, Yoon BH, Thaler HT, Rotmensch S, 500 Romero R. Failure of physiologic transformation of the spiral arteries in patients with preterm labor and intact membranes. Am J Obstet Gynecol 2003;189:1063-9.

[76] Ball E, Bulmer JN, Ayis S, Lyall F, Robson SC. Late sporadic miscarriage is associated with abnormalities in spiral artery transformation and trophoblast invasion. J Pathol $2006 ; 208: 535-42$.

505 [77] Pijnenborg R, Anthony J, Davey DA, Rees A, Tiltman A, Vercruysse L, van Assche A. Placental bed spiral arteries in the hypertensive disorders of pregnancy. $\mathrm{Br} \mathrm{J}$ Obstet Gynaecol 1991;98:648-55.

[78] Madazli R, Somunkiran A, Calay Z, Ilvan S, Aksu MF. Histomorphology of the placenta and the placental bed of growth restricted foetuses and correlation with the Doppler 510 velocimetries of the uterine and umbilical arteries. Placenta 2003;24:510-6. 


\section{Figure legends}

515 Figure 1: a) Anchoring villus showing CTB forming a column from the distal edge of which cytokeratin-positive cells detach to infiltrate the decidua (wax embedded first trimester decidua, 17 weeks gestation, stained with an anti-pan cytokeratin antibody); b) CTB cells in columns within the anchoring villus have arrays of intermediate filaments (IF) associated with desmosomes (D) and elsewhere; c) Fine submembranous filaments (F) can be seen in some areas; here they are prominent at a cyto-syncytial interface in an anchoring villus.

Figure 2: Second trimester placenta, 18 weeks gestation. a) A cytotrophoblast (arrow) can be seen apparently separated from the anchoring villus (though may be attached outside the plane of section), with possible remnants of desmosomes (short white arrows) visible on cell membranes. b) Dark fibrinoid extracellular matrix is present between migrating cells and some gap junctions (arrows) can be seen between adjoining cytotrophoblasts. 